\title{
Development of Polyclonal Antibodies against Mycelial Proteins of Colletotrichum gloeosporioides and Lasiodiplodia theobromae for Serological Detection of Latent Infection in Mango
}

\author{
B. Anusha*, G. Thiribhuvanamala and K. Prabakar \\ Department of Plant Pathology, Tamil Nadu Agricultural University, \\ Coimbatore, Tamil Nadu, India \\ *Corresponding author
}

\section{A B S T R A C T}

Keywords

Mango,

Anthracnose, Stemend rot, Polyclonal antibodies,

Serological detection

Article Info

Accepted:

20 October 2020

Available Online:

10 November 2020
The heavenly fruit, mango, is subject to infection by twenty different genera of fungi from flowering to post-harvest. Among the diseases, anthracnose, caused by Colletotrichum gloeosporioides and stem-end rot, caused by Lasiodiplodia theobromae are the most important. Both $C$. gloeosporioides and L. theobromae cause infection in the field and are carried over to fruits, wherein they remain dormant and establish upon ripening. Thus, unripe fruits that appear healthy during harvest may develop typical symptoms of the diseases upon ripening. Hence, the present study was taken up in order to develop polyclonal antibodies against both the pathogens, for the serological detection of their presence in fruits before fruit ripening.

\section{Introduction}

Anthracnose, caused by Colletotrichum gloeosporoides (Penz. and Sacc.) (teleomorph Glomerella cingulata) and stem-end rot, caused by Lasiodiplodia theobromae (Pat.) Griffon \& Maublanc are the major pre and post-harvest diseases of mango, causing direct yield loss in the field as well as in the packing plant, leading to a significant loss of quality and marketing value thereafter. Both the diseases present great challenges, especially to those involved in international commerce.
In order to combat post-harvest losses, it is important to diagnose the diseases early, so that suitable control measures can be adopted.

Detection of the pathogens is generally done by culturing them on plating media or by serological assays such as Enzyme Linked Immunosorbent Assay (ELISA), Dot Immunobinding Assay (DIBA), and TissueBlot Immunobinding Assay (TBIA) using either monoclonal or polyclonal antisera. ELISA is a highly sensitive, widely accepted immunodetection method for early diagnosis 
of plant pathogens. It has been used to detect the presence of fungal pathogens in seeds (John et al., 1984; Mitchell and Sutherland, 1986) and vegetative tissues (Nachmials, 1979; Savage and Sall, 1981). ELISA was used to detect the presence of the fungal pathogens in Pythium spp., Rhizoctonia solani and Sclerotinia homoeocarpa in golf grass (Miller et al., 1986).

Few studies have previously been made towards serological detection of fungal pathogens by developing antibodies against the particular pathogens. Polyclonal antiserum was raised against a $101 \mathrm{kDa}$ protein of Colletotrichumfalcatum for serological detection of the pathogen in sugarcane by ELISA, DIBA and Western blot (Viswanathan et al., 1998). A monoclonal antibody (UB31) was developed, that could bind to the extracellular matrix surrounding the germ tubes and appressoria of the bean anthracnose fungus, Colletotrichum lindemuthianum (Hutchinson et al., 2002). A polyclonal antiserum raised against a $65 \mathrm{kDa}$ polypeptide from mycelial extracts of $C$. musae was found to react specifically with $C$. musae and the latency of pathogen in sugarcane setts was detected under field conditions (Sible, 2003). Polyclonal antibodies were developed against a $40 \mathrm{kDa}$ protein of $C$. gloeosporioides for serological detection of latent infection of the pathogen in unripe mango fruits (Vivekananthan, 2003).

Early detection of infection in mature but unripe mango fruits would not only reveal the extent of infection, but also would enable the scheduling of management strategies, in order to reduce post-harvest losses. Thus, the present study was undertaken with the aim of developing polyclonal antibodies raised against the purified mycelial proteins of anthracnose and stem-end rot pathogens of mango, to enable their early detection.

\section{Materials and Methods}

\section{Isolation of $C$. gloeosporioides and $L$. theobromae}

The pathogens were isolated from the infected fruits by tissue segment method on potato dextrose agar (PDA) medium (Rangaswami, 1958). The diseased portion was cut along with a portion of the healthy tissue into pieces of $1.0 \mathrm{~cm}$ and surface sterilized with $0.1 \%$ mercuric chloride for one minute. The sterilized tissues were then washed in three changes of sterile distilled water and blot dried on sterilized filter paper.

The dried tissues were placed individually on Petri plates containing PDA medium. The plates were incubated at room temperature $\left(25-30^{\circ} \mathrm{C}\right)$ until pathogen growth. Further, the cultures were purified by single hyphal tip technique and maintained on PDA slants at $4^{\circ} \mathrm{C}$ for further studies.

\section{Extraction of mycelial protein $C$. gloeosporioides and $L$. theobromae}

Mycelial discs of actively growing cultures of C. gloeosporioides and L. theobromae isolates were inoculated into $100 \mathrm{ml}$ of potato dextrose broth in conical flasks and incubated at room temperature $\left(25-30^{\circ} \mathrm{C}\right)$ for seven days.

The mycelial mats were harvested, blot dried on sterile filter paper and homogenized with liquid nitrogen. One gram of powdered mycelial sample was extracted with one $\mathrm{ml}$ of $0.1 \mathrm{M}$ potassium phosphate buffer $(\mathrm{pH} \mathrm{7.0)}$ at $4^{\circ} \mathrm{C}$. The homogenate was centrifuged for 20 min at $10,000 \mathrm{rpm}$ and the supernatant was used as the protein source. The proteins were quantified by Bradford method (Bradford, 1976) and then used for sodium dodecyl sulphate polyacrylamide gel electrophoresis (SDS-PAGE) (Laemmli, 1970). 
Protein profiling of $C$. gloeosporioides and L. theobromae by SDS-PAGE

The protein sample of each isolate $(40 \mu \mathrm{l})$ was mixed with $10 \mu \mathrm{l}$ of sample buffer in a microfuge tube, boiled for $3 \mathrm{~min}$ at $100^{\circ} \mathrm{C}$ and placed in ice immediately. The samples were loaded into the wells of polyacrylamide gels (Sigma-Aldrich Techware system, Sigma, USA). Medium range molecular weight markers (Bangalore Genei, India) were used. Electrophoresis was carried out at a constant voltage of $75 \mathrm{~V}$ and the gels were incubated overnight in staining solution containing 0.2 per cent Coomassie brilliant blue (R250). The gels were then destained until the protein bands were clearly visible. The common protein pertaining to all the isolates of the two pathogens was identified.

Purification of single protein of $C$. gloeosporioides and L. theobromae

Upon identifying the common protein corresponding to all the isolates, the mycelial protein of the virulent isolate of the each of the pathogens was used for further studies. The frozen mycelia of the virulent isolate of the pathogens were homogenized in $250 \mathrm{ml}$ of $0.1 \mathrm{M}$ potassium phosphate buffer $(\mathrm{pH} 7.0)$ using a pre-chilled pestle and mortar. The homogenates were centrifuged at $12,000 \mathrm{rpm}$ for $20 \mathrm{~min}$ in a refrigerated centrifuge at $4^{\circ} \mathrm{C}$ and the supernatant solutions were collected. Ammonium sulphate was added to the supernatant to precipitate the proteins at different saturation levels viz., 0-20, 20-40, 40-60 and 60-80 per cent saturation and incubated at $4{ }^{\circ} \mathrm{C}$ overnight under constant stirring.

Each fraction was collected separately by centrifugation at $10,000 \mathrm{rpm}$ for $20 \mathrm{~min}$ at $4^{\circ} \mathrm{C}$. The precipitates were dissolved in $5 \mathrm{ml}$ of extraction buffer and dialyzed against the same buffer using dialysis membrane with molecular cut off of 12,000 to 14,000 Dalton (Spectra/Por, SPECTRUM Laboratories, CA, USA.). Each ammonium sulphate fraction was then analyzed by SDS-PAGE, the protein band was cut out from the gel and electroeluted for $3 \mathrm{~h}$ at $12 \mathrm{~mA}$ against $0.1 \mathrm{M}$ potassium phosphate buffer.

\section{Production of polyclonal antiserum against the purified mycelial proteins}

The purified proteins of $C$. gloeosporioides and $L$. theobromae were used for raising polyclonal antisera (PCA) in rabbits by intramuscular immunization method (Bollen et al., 1996). Adult New Zealand white rabbits weighing about $1.5 \mathrm{~kg}$ ( 3 months old) were purchased and used for the study. Around $500 \mu \mathrm{g}$ protein was used for each immunization. Freund's complete adjuvant $(1.0 \mathrm{ml})$ was added to $1.0 \mathrm{ml}$ of antigen $(500$ $\mu \mathrm{g}$ protein $/ \mathrm{ml})$. The contents were mixed thoroughly and taken in a sterile syringe with $22 \mathrm{G}$ needle and administered intramuscularly.

Four injections were given at weekly intervals and a booster injection was given a week after the last injection, with the same quantity of antigen added with Freund's incomplete adjuvant. Fifteen days after the fourth injection, blood sample was collected from the marginal ear vein in sterile glass vials. The vials were immediately placed in a slanting position, so as to enable clotting of blood and separation of serum. The antiserum was carefully collected in sterile centrifuge tubes and the red blood cells were pelleted by centrifuging at $8000 \mathrm{rpm}$ at $4^{\circ} \mathrm{C}$ for $10 \mathrm{~min}$ three times. Finally, the serum was transferred to sterile microfuge tubes and stored at $-70^{\circ} \mathrm{C}$ until further use.

\section{Standardization of antibody dilution by Indirect ELISA}

Indirect ELISA (Enzyme Linked Immunosorbent Assay) was performed to 
standardize the dilution factor for the antibodies, according to already established procedure (Hobbs et al., 1987). Dilutions of antibody ranging from $1: 10$ to $1: 10,000$ were prepared with $0.1 \mathrm{M}$ phosphate buffer $(\mathrm{pH} 7.0)$ and used for the standardization. Wells of polystyrene microtitre plate (Immunolon-2Removawells; Dynatech Laboratories, Alexandria) were coated with $100 \mu$ l of the antigen and incubated overnight at $4^{\circ} \mathrm{C}$. The plate was then washed with $0.01 \mathrm{M}$ phosphatebuffered saline (PBS) (pH 7.2), containing 0.02 per cent $(\mathrm{v} / \mathrm{v})$ Tween 20 (PBS-T) thrice, at 3 min interval.

After washing, $100 \mu$ l of each dilution of antibody was added to each well and incubated at $37^{\circ} \mathrm{C}$ for $4 \mathrm{~h}$. The plate was then washed three times with PBS-T and $100 \mu \mathrm{l}$ of AP-labelled goat anti-rabbit immunoglobulin (GeNei, Bangalore, India) was added at 1:8000 dilution to each well. The plate was incubated at $37^{\circ} \mathrm{C}$ for $4 \mathrm{~h}$ and then washed with PBS-T thrice. Finally, $100 \mu$ l of freshly prepared $p$-nitrophenyl phosphate (1.0 $\mathrm{mg} / \mathrm{ml}$ )in 0.2M Tris buffer $\mathrm{pH}$ 7.0, (Sigma FAST, Sigma, USA) was added to each well and incubated at $37^{\circ} \mathrm{C}$ for $30 \mathrm{~min}$ for colour development. The optical density was measured at $405 \mathrm{~nm}$ in an ELISA reader.

\section{Serological detection of pathogens in mango fruits by indirect ELISA}

For testing the reactivity of the PCA for detection of the pathogen under field conditions, fruit samples were collected from mango orchards at random. Fully mature but unripe fruits were used for the serological assays. The fruit peel samples were homogenized in $0.1 \mathrm{M}$ phosphate buffer $\mathrm{pH}$ $7.0(1: 1 \mathrm{w} / \mathrm{v})$ and used as the antigen. Indirect ELISA was performed separately for the two pathogens using the polyclonal antibodies raised against the corresponding pathogen.

\section{Results and Discussion}

\section{Isolation of $C$. gloeosporioides and $L$. theobromae}

A total of twenty isolates of $C$. gloeosporioides and sixteen isolates of $L$. theobromae were collected from the major mango growing regions of Tamil Nadu, India. They were isolated on PDA medium and designated as $C g$ 1-20 for $C$. gloeosporioides and $L t$ 1-16 for $L$. theobromae. The pathogens were characterized morphologically based on the mycelialcolour, growth pattern and sporulation and molecularly characterized by PCR amplification of the ITS regions. Further, the pathogenicity of the isolates was proved by inoculating the isolates of $C$. gloeosporioides and L. theobromae separately onto healthy mango fruits and typical symptoms of anthracnose and stem-end rot were observed for all the isolates.Among the isolates, $C g-4$ of C. gloeosporioides and $L t-14$ of $L$. theobromae were identified as the most virulent.

\section{Protein profiling of $C$. gloeosporioides and L. theobromae isolates}

The protein profile of the C. gloeosporioides isolates showed the presence of proteins of molecular weight ranging from $14.7 \mathrm{kDa}$ to $97.4 \mathrm{kDa}$. While some of the isolates displayed few protein bands on the gel, certain isolates like $C g-4, C g-10$ and $C g-13$ produced several discrete bands. Among the various proteins obtained in the profile, two common protein bands of size $70 \mathrm{kDa}$ and $40 \mathrm{kDa}$ pertaining to all the isolates were observed.

The crude mycelial proteins of the virulent isolate, $C g-4$ were subjected to ammonium sulphate fractionation. Among the different fractions subjected to SDS-PAGE the 80 per cent fraction showed the maximum 
expression of the required proteins. The proteins of molecular weight $40 \mathrm{kDa}$ and $70 \mathrm{kDa}$ of $\mathrm{Cg}-4$ were eluted from the gel, purified by dialysis and lyophilized. The purified proteins were then used for raising antibodies in New Zealand white rabbits.

The profile of the sixteen $L$. theobromae isolates by SDS-PAGE revealed diverse proteins, most of which were in the range of $30.0 \mathrm{kDa}$ to $97.4 \mathrm{kDa}$. The common protein band expressed by most of the isolates corresponded toa molecular weight of $70 \mathrm{kDa}$. The $70 \mathrm{kDa}$ protein of the most virulent isolate, $L t-14$ was subjected to ammonium sulphate fractionation. Since the 80 per cent fraction showed maximum expression upon SDS-PAGE analysis, the corresponding protein was eluted from the gel, purified by dialysis and lyophilized. The purified protein thus obtained was used for raising antibodies.

\section{Standardization of antibody dilution by ELISA}

Standardization of the dilution factor of the primary antibodies raised against the mycelial proteins of $C$. gloeosporioides revealed that at all the dilutions, the antibodies reacted with the antigen and each dilution revealed a varied OD value. Based on the comparison of the OD value with that of buffer, the highest reactivity was arrived at. Accordingly, the highest OD value of 0.816 was obtained at the dilution ratio of 1:1000 for the $40 \mathrm{kDa}$ protein. An OD value of 1.028 was obtained for the dilution of $1: 3000$ for the $70 \mathrm{kDa}$ protein. These dilutions were found to be optimum for the significant detection of C. gloeosporioides in ELISA. In case of $L$. theobromae, the antibody dilutions of 1:1000 showed the highest OD value of 0.860 and were standardized as the ideal dilution for antigen detection by ELISA (Table 1).

Table.1 Standardization of antibody dilution of $C$. gloeosporioides and L. theobromae by ELISA

\begin{tabular}{|c|c|c|c|c|c|c|c|c|c|}
\hline $\begin{array}{l}\text { Dilution } \\
\text { factor } \\
\text { Antibody }\end{array}$ & $1: 50$ & $1: 100$ & $1: 500$ & 1:1000 & $1: 3000$ & $1: 5000$ & $1: 7000$ & 1:10000 & Buffer \\
\hline Cg $40 \mathrm{kDa}$ & 0.794 & 0.867 & 0.633 & 0.816 & 0.692 & 0.419 & 0.392 & 0.305 & 0.249 \\
\hline Cg 70 kDa & 0.632 & 0.670 & 0.710 & 0.755 & 1.028 & 0.747 & 0.585 & 0.450 & 0.191 \\
\hline$L t 70$ kDa & 0.778 & 1.018 & 1.103 & 0.860 & 0.808 & 0.584 & 0.351 & 0.300 & 0.284 \\
\hline
\end{tabular}

Table.2 Detection of latent infection of C. gloeosporioides and L. theobromae in mango fruits by ELISA

\begin{tabular}{|c|c|c|c|c|c|c|c|c|c|c|c|c|}
\hline $\begin{array}{l}\text { Sample } \Longrightarrow \\
\text { Antibody }\end{array}$ & 1 & 2 & 3 & 4 & 5 & 6 & 7 & 8 & 9 & 10 & $\begin{array}{c}\text { Infected } \\
\text { sample }\end{array}$ & $\begin{array}{c}\text { Buffe } \\
\mathbf{r}\end{array}$ \\
\hline Cg 40 kDa & 0.302 & 0.270 & 0.351 & 0.368 & 0.295 & 0.284 & 0.351 & 0.277 & 0.271 & 0.206 & 0.418 & 0.181 \\
\hline$C g$ 70kDa & 0.462 & 0.355 & 0.377 & 0.210 & 0.245 & 0.286 & 0.328 & 0.277 & 0.265 & 0.245 & 0.474 & 0.221 \\
\hline$L t 70 \mathrm{kDa}$ & 0.415 & 0.519 & 0.440 & 0.383 & 0.432 & 0.394 & 0.491 & 0.414 & 0.332 & 0.307 & 0.527 & 0.180 \\
\hline
\end{tabular}

Detection of latency in mango fruits by ELISA

The infected fruit samples recorded the highest absorbance in ELISA at $405 \mathrm{~nm}$ for all the three antibodies corresponding to $C$. gloeosporioides and L. theobromae. The OD values of fruit samples tested against the 40kDa antibody of $C$. gloeosporioides ranged from 0.206 to 0.368 . The samples number 3 
and 7 recorded OD values of 0.351 and sample number 4 showed an OD value of 0.368 , which was much lesser than that of the OD value of the infected fruits, which was 0.418 . In case of the $70 \mathrm{kDa}$ antibody of $C$. gloeosporioides, sample number 1 was found to show an OD value of 0.462 , which was comparable to that of infected sample (OD value 0.474$)$. All the other samples recorded lesser OD values (Table 2).

Among the fruit samples tested against the $70 \mathrm{kDa}$ antibody of $L$. theobromae, the OD values ranged from 0.307 to 0.519 . The fruit samples number 2 and 7 recorded OD values of 0.519 and 0.491 respectively, which was comparable to the OD value of infected sample (0.527) (Table 2).

Detecting the infection of $C$. gloeosporioides and $L$. theobromae in mango fruits at the early stages of fruit development is difficult, as they remain latent in the young fruits and express only upon ripening. Unripe fruits are known to contain more starch and phenol, which are preformed inhibitors that interfere with the establishment of the pathogen (Verhoeff, 1974). Detection of the prevalence and identification of a pathogen is very essential for adequate and timely management of diseases. Thus, it is most essential to accurately diagnose and detect the presence of the pathogen at an early stage.

Over the past two decades, ELISA has been widely accepted as a highly sensitive immunodetection technique for latent infections, as it allows for specific detection and simultaneous analysis of many samples in a single microplate. ELISA involves the binding of an antigen to a specific antibody against which the antibody was raised, thus enabling very specific and reliable detection. Many workers have used ELISA for the specific detection of latent infections. The polyclonal antiserum raised against $101 \mathrm{kDa}$ polypeptide was highly specific in detecting the red rot pathogen, $C$. falcatum in sugarcane setts (Viswanathan et al., 1998). The latent infection of the strawberry anthracnose pathogen, $C$. acutatum was diagnosed in apparently healthy roots, crowns, petioles and fruits using ELISA and DIBA techniques (Kratka, 2002). The latent infection of $C$. gloeosporioides in mango was detected using polyclonal antibodies raised against a $40 \mathrm{kDa}$ protein of the pathogen (Vivekananthan, 2003).

In the present study, prior to ELISA, based on the protein profiles of the isolates of the two pathogens, viz., C. gloeosporioides $(\mathrm{Cg}-4)$ and L. theobromae (Lt-14), analysed by SDSPAGE (Anusha and Prabaka, 2014), the common proteins expressed by all the isolates were identified and used to develop polyclonal antibodies for the immunological detection of infection in unripe mango fruits. Using the standardized dilutions of the raised antibodies, ELISA was performed for fruit samples collected randomly from mango orchards. Few of the test samples recorded high OD values that were comparable to that of infected fruits, thereby revealing the probable presence of the pathogen in the samples. The other samples were assumed to be free from infection.

In conclusion the several studies have been made to detect the presence of pathogens in latent stage in various food crops. In the present study, polyclonal antibodies were raised against purified mycelial proteins of $C$. gloeosporioides and L. theobromae, the two important pathogens of mango responsible for post-harvest losses. Since the proteins used for raising antibodies were common and represented isolates collected from the major mango growing regions of Tamil Nadu, the antibodies so raised would be useful to detect the races of the two pathogens from the different mango growing regions of the state. 
This would be further helpful to adopt suitable management strategies to minimize loss of the precious mango fruits.

\section{Acknowledgement}

We are thankful to International Development Research Centre (IDRC), Canada, for funding the project.

\section{Conflict of interest}

The authors declare that they have no conflict of interest.

\section{References}

Anusha, B. and Prabaka, K. 2014. Purification of mycelial proteins of Colletotrichum gloeosporioides and Lasiodiplodia theobromae of mango for production of polyclonal antibodies. Trends in Biosci.7(19): 2922-2925.

Bollen, S.L., Crowley, A., Stodulski, G. and Hau, J. 1996. Antibody production in rabbits and chickens immunized with human IgG. A comparison of titre and avidity development in rabbit serum, chicken serum and egg yolk using three different adjuvants. J, Immunol. Metho.,191:113-120.

Bradford, M.M. 1976. A rapid and sensitive method for the quantification of microgram of proteins utilizing the principles of protein dye binding. Analytical Biochem., 72: 248-254.

Hobbs, H.A., Reddy, D.V.R., Rajeswari, R and Reddy, A.S. 1987. Use of direct antigen coating and protein A coating ELISA procedures for detection of three peanut viruses. Plant Dis.,71: 747-749.

Hutchison, K.A., Green, J.R., Wharton, P.S. and Connell, J. 2002. Identification and localization of glycoproteins in the extracellular matrices around germ tube and appressoria of Colletotrichum species. Mycol. Res., 106(6): 729-736.

John, R., Schiebeker, W. and Greengard, P. 1984. A quantitative dot immunobinding assay for proteins using nitrocellulose membrane filters. In Proceedings of the National Academy of Sciences, USA. 81:16841689.

Johnson G.I. and Coates L.M. 1993. In Postharvest diseases of mango: Postharvest and information, 4:27-34.

Kratka, J., Blanka, P.K., Iva, K. Jalub, S. and Michaela, Z. 2002. Models of action of (2E)-alkenals against Saccharomyces cerevisiae, J. Agric. Food Chem., 51: 3951-3957.

Laemmli, U.K. 1970. Cleavage of structural proteins during the assembly of the head of bacteriophage T4. Nature,227: 680-685.

Miller, S.A., Grothaus, G.D., Peterse, F.P. and Papa, S. 1986. Detection of Pythium blight in turfgrass using a monoclonal antibody based diagnostic test. Phytopathology, 76: 1057.

Mitchell, L.A. and Sutherland, J.R. 1986. Detection of seed borne Sirococcus sterobilinus with monoclonal antibodies in an enzyme linked immunosorbent assay. Can. J. For. Res., 16: 945-948.

Nachmials, A., Bar-Joseph, M., Solel, Z. and Barash, I. 1979. Daignosis of malsecco disease in lemon by enzyme linked immunosorbent assay. Phytopathology, 69: 559-561.

Rangaswami, G. 1958. An agar block technique for isolating soil micro organisms with special reference to Pythiaceous fungi. Science and Culture, 24: 85-94.

Savage, S.D. and Sall, M.A. 1981. Radio immunoassay for Botrytis cinerea. Phytopathology, 71: 411-415.

Sible, G. V. 2003. Biotechnology based 
approaches for the early detection and management of post-harvest anthracnose in banana. Ph.D. (Ag.) thesis, Tamil Nadu Agricultural University, Coimbatore, India, pp.167.

Snowdon A.L. 1990. In A Color Atlas of Postharvest Diseases and Disorder of Fruits and Vegetables, Vol. I: General Introduction and Fruits.

Verhoeff, K. 1974. Latent infection by fungi. Ann. Rev. Phytopath., 12: 99-109.

Viswanathan, R., Samiyappan, R. and
Padmanaban, P. 1998. Specific detection of Colletotrichum falcatum in sugarcane by serological techniques. Sugarcane, 3: 18-23.

Vivekananthan, R. 2003. Biotechnology based approaches for early detection and management of anthracnose disease in mango. Ph.D. Thesis, Department of Plant Pathology, Tamil Nadu Agricultural University, Coimbatore.

\section{How to cite this article:}

Anusha, B., G. Thiribhuvanamala and Prabakar, K. 2020. Development of Polyclonal Antibodies against Mycelial Proteins of Colletotrichum gloeosporioides and Lasiodiplodia theobromae for Serological Detection of Latent Infection in Mango. Int.J.Curr.Microbiol.App.Sci. 9(11): 2157-2164. doi: https://doi.org/10.20546/ijcmas.2020.911.256 